\title{
Monoblast Count
}

National Cancer Institute

\section{Source}

National Cancer Institute. Monoblast Count. NCI Thesaurus. Code C74631.

The determination of the number of monoblast cells present in a sample. 